\title{
Last Glacial climate reconstruction by exploring glacier sensitivity to climate on the southeastern slope of the western Nyaiqentanglha Shan, Tibetan Plateau
}

\author{
XIANGKE XU, ${ }^{1,2}$ BAOLIN PAN, ${ }^{3}$ GUOCHENG DONG, ${ }^{4} \mathrm{CHAOLU}_{\mathrm{YI}},{ }^{1,5}$ \\ NEIL F. GLASSER ${ }^{6}$ \\ ${ }^{1}$ Key Laboratory of Tibetan Environment Changes and Land Surface Processes, Institute of Tibetan Plateau Research, CAS, \\ Beijing 100101, China \\ ${ }^{2}$ State Key Laboratory of Cryospheric Sciences, Cold and Arid Regions Environmental and Engineering Research Institute, \\ CAS, Lanzhou 730000, China \\ ${ }^{3}$ College of Resources, Environment and Tourism, Capital Normal University, Beijing 100048, China \\ ${ }^{4}$ State Key Laboratory of Loess and Quaternary Geology, Institute of Earth Environment, Chinese Academy of Sciences, \\ Xi'an 710061, China \\ ${ }^{5}$ CAS Center for Excellence in Tibetan Plateau Earth Sciences, Beijing 100101, China \\ ${ }^{6}$ Department of Geography and Earth Sciences, Centre for Glaciology, Aberystwyth University, Aberystwyth SY233DB, UK \\ Correspondence: Xiangke $\mathrm{Xu}<x k x u @ i t p c a s . a c . c n>$
}

\begin{abstract}
Improvements in understanding glacial extents and chronologies for the southeastern slope of the western Nyaiqentanglha Shan on the Tibetan Plateau are required to understand regional climate changes during the Last Glacial cycle. A two-dimensional numerical model of mass balance, based on snow-ice melting factors, and of ice flow for mountain glaciers is used to assess the glacier sensitivity to climatic change in a catchment of the region. The model can reproduce valley glaciers, widetongued glaciers and a coalescing glacier within step temperature lowering and precipitation increasing experiments. The model sensitivity experiments also indicate that the dependence of glacier growth on temperature and/or precipitation is nonlinear. The model results suggest that the valley glaciers respond more sensitively to an imposed climate change than wide-tongued and coalescing glaciers. Guided by field geological evidence of former glacier extent and other independent paleoclimate reconstructions, the model is also used to constrain the most realistic multi-year mean temperatures to be $2.9-4.6^{\circ} \mathrm{C}$ and 1.8-2.5 ${ }^{\circ} \mathrm{C}$ lower than present in the glacial stages of the Last Glacial Maximum and middle marine oxygen isotope stage 3 , respectively.
\end{abstract}

KEYWORDS: glacier and climate, Last Glacial, numerical glacier modeling, western Nyaiqentanglha Shan

\section{INTRODUCTION}

The Tibetan Plateau and its surrounding mountains are among the most prominent topographic features on the Earth. Through time, the uplift of the Tibetan Plateau has caused environmental changes, brought about by the initiation of the South Asian monsoon and the splitting of the Northern Hemisphere westerlies into two branches (Prell and Kutzbach, 1992; Raymo and Ruddiman, 1992; Benn and Owen, 1998). Moreover, the variations of the Northern Hemisphere ice sheet are expected to exert influences on the climate change of the Tibetan Plateau, through storm tracks of cold air and westerly circulations (Porter and An, 1995; Benn and Owen, 1998; Zhou and others, 1999). Therefore, the Tibetan Plateau has a profound connection to global and regional climate (Molnar and England, 1990; Owen and Benn, 2005). Understanding the Quaternary glaciations of the Tibetan Plateau can therefore yield valuable information on the evolution of Earth's climate system.

Previous studies have extensively focused on the timing and style of the Quaternary glaciations on the Tibetan Plateau, based on glacial landform mapping, relative age controls from landform weathering features and morphostratigraphy, and numerical dating technologies, including radiocarbon ${ }^{14} \mathrm{C}$, optically stimulated luminescence and cosmogenic radionuclides (CRN). Of importance are studies that have used CRN methods to constrain the timing of glaciations. About 1855 individual exposure ages from 485 glacial deposits have been reported across the Tibetan Plateau (Heyman, 2014). Several glacial periods across the Tibetan Plateau have been identified based on the CRN methods: the Little Ice Age, Neoglacial, midHolocene, early Holocene, late glacial, global Last Glacial Maximum (LGM; marine oxygen isotope stage 2 (MIS 2)), middle last glacial (MIS 3) and early last glacial (MIS 4) (Owen and others, 2008; Owen and Dortch, 2014). Furthermore, using a robust statistical method, Dortch and others (2013) and Murari and others (2014) respectively recognized 19 and 27 regional glacial stages across the semi-arid western regions and the monsoon-influenced regions of the Himalayan-Tibetan orogeny. These studies allow us to compare the timings of glacial events at different sites and thus to construct a chronological framework for regional glaciations. They also make it possible to understand the climatic drivers for the glaciations of the Tibetan Plateau by correlation with other independent climate-proxy records. Indeed, current studies of Tibetan Plateau glaciations are focused on these two points, enabling a reasonably complete picture of late Quaternary glaciations to emerge. However, 


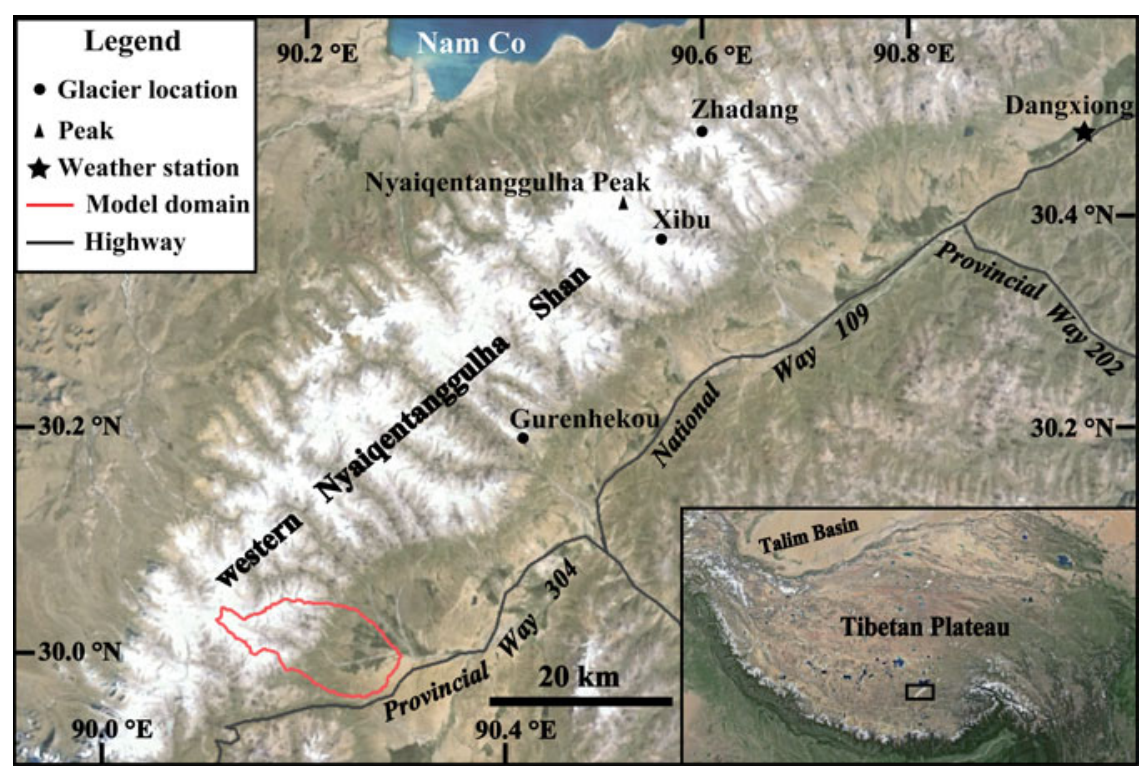

Fig. 1. Location of the model domain on the southeastern slope of the western Nyaiqentanglha Shan and southern Tibetan Plateau. The red line delineates the model domain.

quantitative reconstructions of the Tibetan Plateau glaciations, such as the glacier mass balance, ice volume and possible climate conditions during each glacial episode, still require further study on the basis of the chronological framework of the Tibetan Plateau glaciations.

Numerical modeling of former glaciers can be an effective method of inferring paleoclimate, particularly when constrained by glacier-related geomorphologic features (Hostetler and Clark, 2000; Plummer and Phillips, 2003; Blard and others, 2007). Paleo-glacier simulations therefore add understanding of glacial climatic conditions, while also providing an independent method by which to allow paleo-glaciers to be reconstructed based on geological or geomorphological field evidence (Le Meur and Vincent, 2003; Plummer and Phillips, 2003). During recent years glacier-climate modeling work has been carried out on parts of the Tibetan Plateau (Xu and others, 2013; Xu, 2014; Wang and others, 2015). However, because the vast Tibetan Plateau is influenced by different climate systems, such modeling work needs to be carried out in different parts of the region, in order to fully understand the relationships between glacier fluctuations and climatic changes. In this study, we focus our glacier-climate modeling efforts on the southeastern slope of the western Nyaiqentanglha Shan (Fig. 1). Specifically, this study aims to test glacier sensitivity to climate change and infer possible climate conditions that could have supported the glacier extents during the Last Glacial period, through simulating the glacier extents at a catchment scale under different climate scenarios.

\section{STUDY AREA}

The western Nyaiqentanglha Shan stretches $\sim 250 \mathrm{~km}$ from SW to NE on the southern Tibetan Plateau and includes more than 30 peaks over $6000 \mathrm{~m}$ asl, with the highest at $7117 \mathrm{~m}$ asl (Nyaiqentanglha Peak, Yu and others, 2013). The South Asian monsoon, carrying moisture from the Indian Ocean, dominates in summer; and the westerly circulations derived from the Mediterranean Sea and/or the Atlantic Ocean dominate in winter (Yatagai and Yasunari,
1998; Shi, 2002). This produces a distinct seasonal oscillation of the climate with warm-wet summers (MaySeptember) and cold-dry winters (October-April). Observations at Dangxiong Weather Station $\left(30^{\circ} 29^{\prime} \mathrm{N}, 91^{\circ}\right.$ $06^{\prime} \mathrm{E}, 4200 \mathrm{~m}$ asl), indicate that in the period 1981-2010 the mean annual temperature was $2.06^{\circ} \mathrm{C}$ and the mean annual precipitation was $478 \mathrm{~mm}$. More than $90 \%$ of the precipitation is delivered between May and September (Fig. 2).

During the Late Quaternary, the western Nyaiqentanglha Shan was intensively glaciated, and many moraines were formed and preserved in the glaciated valleys ( $\mathrm{Li}$ and others, 1986; Owen and others, 2005; Chevalier and others, 2011; Dong and others, 2014). Two sets of moraines are present near valley mouths on the southeastern slope of the western Nyaiqentanglha Shan (Fig. 3a). The inner moraine set consists of latero-frontal moraines that are typically perched within the valleys and extend down to the valley mouths. The moraines of this set were deposited by individual valley glaciers. The outer moraine set is characterized by subdued ridges radiating from the mountain front. These ridges extend $\sim 2 \mathrm{~km}$ southeast of the range front and terminate at altitudes of 4760-4850 m asl. We interpret these as moraines formed by a coalescing glacier that advanced out of the mountains into the range foreland. The two sets of moraines indicate two glacial expansions relative to the contemporary status, corresponding to different climate conditions. Accordingly, this paper focuses on simulating the respective glacier extents constrained by the two moraine sets and inferring the possible climate conditions that supported these glacier advances.

Using cosmogenic ${ }^{10} \mathrm{Be}$ exposure dating, Chevalier and others (2011) dated five and 22 boulder samples for the inner and outer moraine sets, respectively. The ages on the inner moraine set range from $10.4 \pm 0.9$ to $20.3 \pm 1.8 \mathrm{ka}$, calculated using the time-dependent ${ }^{10} \mathrm{Be}$ production rate scaling model of Lal (1991) and Stone (2000), and the ages on the outer set spread even wider (from $12.6 \pm 1.1$ to 49.8 $\pm 4.4 \mathrm{ka}$ ). The wide spread of the ${ }^{10} \mathrm{Be}$ ages makes it difficult to assign the moraines to specific glaciations. On the northwestern slope of the western Nyaiqentanglha Shan, Dong and others (2014) also dated two moraine sets near the 


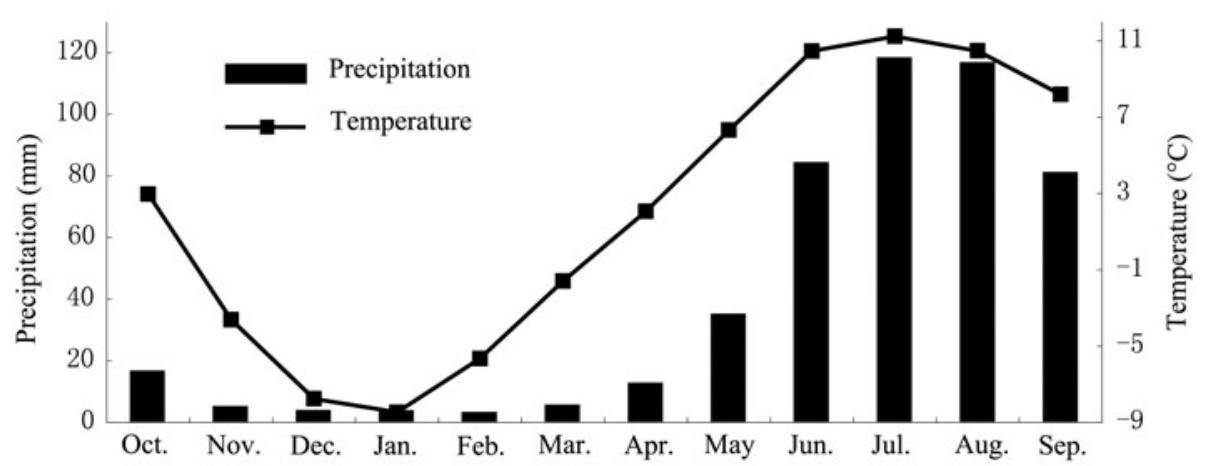

Fig. 2. The monthly averaged temperature and precipitation for the period of $1981-2010$ at the Dangxiong weather station $\left(30^{\circ} 29^{\prime} \mathrm{N}, 91^{\circ} 06^{\prime} \mathrm{E}\right.$, $4200 \mathrm{~m}$ asl).
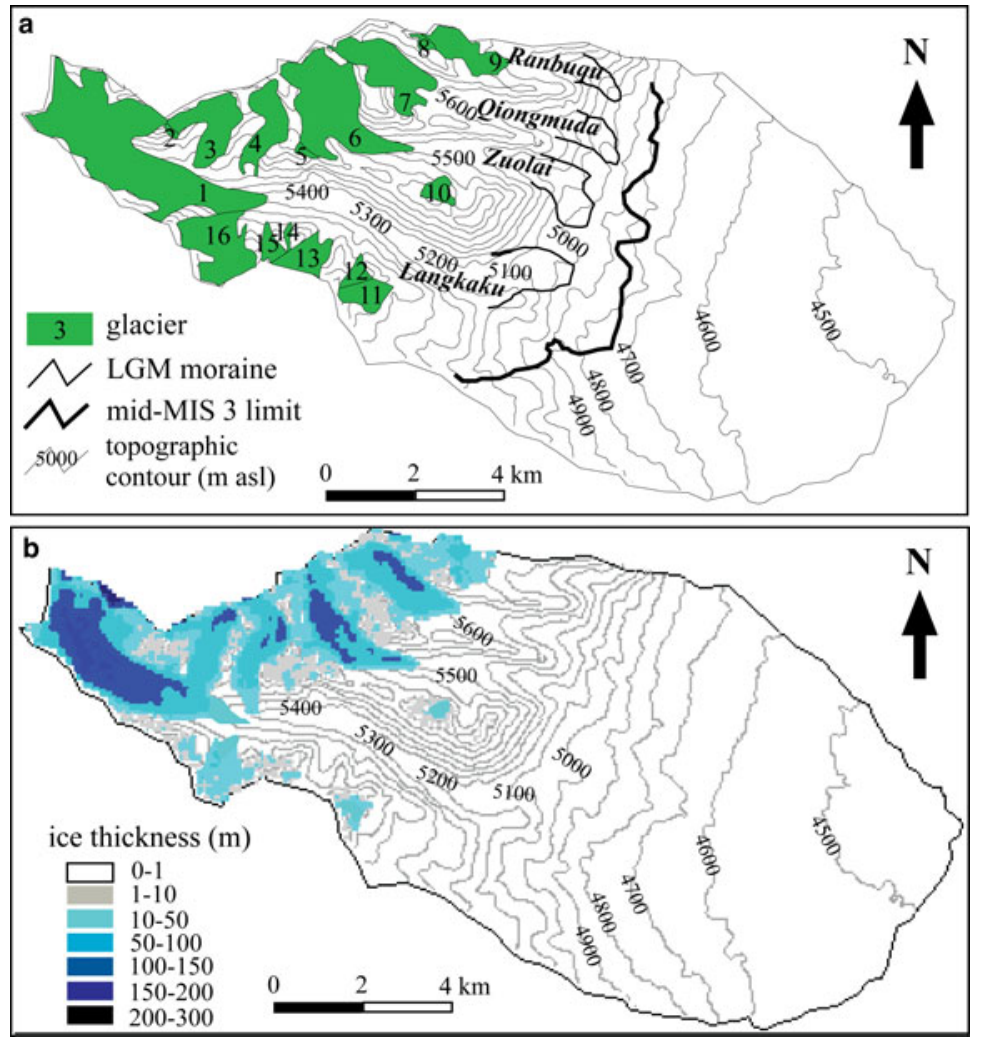

Fig. 3. Comparison of the glacial distribution for (a) observed and (b) modeled glaciers under modern climate conditions, based on an ice $D D F_{\mathrm{i}}$ of $11.8 \mathrm{~mm}{ }^{\circ} \mathrm{C}^{-1} \mathrm{~d}^{-1}$. Note that the LGM and mid-MIS 3 glacier limits are delineated by field geological evidence.

mouth of the Payuwang Valley, which have similar morphostratigraphic settings to the moraines of this study. Dong and others (2014) assigned the respective ages of $23.8 \pm 4.0$ and $39.9 \pm 3.7 \mathrm{ka}$ to the two moraine sets and argued that the glaciers expanded during LGM and MIS 3 in the western Nyaiqentanglha Shan. In addition, by separating Gaussians from cumulative probability frequency distributions to obtain best fits on the ${ }^{10} \mathrm{Be}$ data, Murari and others (2014) recalculated the ages for the two moraine sets. They assigned an age of $12.5 \pm 3.1 \mathrm{ka}$ to the inner moraine set and three ages of $58.1 \pm 7,35.3 \pm 7.4$ and $25.4 \pm 8.6 \mathrm{ka}$ to the outer set. However, using an updated global reference ${ }^{10}$ Be production rate and a more robust statistical method, Heyman (2014, in Appendix file) showed that the inner moraine set has an age of $22.2 \pm 9.0 \mathrm{ka}$, and the outer set has ages of $56.0 \pm 27.7,55.4 \pm 16.9$ and $26.2 \pm 12.2 \mathrm{ka}$. According to these ${ }^{10} \mathrm{Be}$ ages, we ascribe the inner moraine set to the LGM. Although it is difficult to rule out the possibility that the outer moraine formed during MIS 4, there are other ${ }^{10}$ Be dates indicating that the glaciers advanced during MIS 3 (60-30 ka) influenced by the Asian summer monsoon in the Himalaya, Anyemaqen, Nianbaoyeze and Qilian Mountains (e.g. Finkel and others, 2003; Owen and others, 2003; Wang and others, 2013; Murari and others, 2014; Owen and Dortch, 2014). In addition, Shi and others (2000) investigated 23 glaciated sites distributed in 12 areas in Asia, Europe, America and Australia and concluded that during MIS 3, glacial expansion happened in those regions. Based on the isotopic record preserved in the Guliya ice core, Shi and Yao (2002) identified three substages in MIS 3 (MIS 3a, b and c) and argued that the coldand-wet climate of MIS 3b (44-54 ka) favored glacier 
Table 1. Cataloged modern glaciers with an area larger than $0.5 \mathrm{~km}^{2}$ in the model domain

\begin{tabular}{|c|c|c|c|c|c|c|c|}
\hline & $\begin{array}{l}\text { Latitude* } \\
{ }^{\circ} \mathrm{N}\end{array}$ & $\begin{array}{l}\text { Longitude* } \\
{ }^{\circ} \mathrm{E}\end{array}$ & Type & $\begin{array}{l}\text { Area } \\
\mathrm{km}^{2}\end{array}$ & $\begin{array}{l}\text { Length } \\
\mathrm{km}\end{array}$ & $\begin{array}{l}\text { Terminal altitude } \\
\mathrm{m} \text { asl }\end{array}$ & Flow direction \\
\hline 1 & 30.00 & 90.17 & Compound glacier & 5.87 & 5.4 & 5481 & $\mathrm{E}$ \\
\hline 3 & 30.01 & 90.15 & Compound glacier & 1.24 & 1.9 & 5695 & SW \\
\hline 4 & 30.00 & 90.17 & Valley glacier & 1.03 & 1.7 & 5720 & $\mathrm{~S}$ \\
\hline 6 & 30.01 & 90.20 & Compound glacier & 2.98 & 2.7 & 5597 & $\mathrm{E}$ \\
\hline 7 & 30.02 & 90.21 & Valley glacier & 1.64 & 2.2 & 5672 & SE \\
\hline 11 & 29.98 & 90.20 & Cirque glacier & 0.51 & 1.0 & 5759 & SSE \\
\hline 13 & 29.99 & 90.19 & Cirque glacier & 0.62 & 0.9 & 5577 & NNE \\
\hline 16 & 29.99 & 90.17 & Cirque glacier & 1.63 & 1.8 & 5530 & $\mathrm{~N}$ \\
\hline
\end{tabular}

* Denotes glacier terminal.

expansion. Accounting for this evidence, combined with the recalculated ages by Murari and others (2014) and Heyman (2014), we speculate that the outer moraine set most likely corresponds to a glacier advance that occurred during midMIS 3, but acknowledge here that such age estimate is a working hypothesis until more data are available. Such understanding of the glacial chronologies provides a framework for modeling glacier extents and inferring related climatic changes.

\section{METHODS}

The paper simulates the glacier extents during the LGM and mid-MIS 3 that are constrained by the glacial geomorphologic features and cosmogenic ${ }^{10} \mathrm{Be}$ exposure ages on the southeastern slope of the western Nyaiqentanglha Shan. To do this, we use a coupled two-dimensional (2-D) massbalance and shallow ice-flow model that was previously used to model mountain glacier extents on the northwestern and eastern parts of the Tibetan Plateau (Plummer and Phillips, 2003; Xu and others, 2014). The basis and strategy for the modeling are presented in these previous studies, and here we focus on the model input and model parameterization that are necessary to run the model in the study area.

\subsection{Input data}

The input data for the glacier-climate model include a DEM to represent the subglacial bed topography and monthly averaged climate records of temperature and precipitation. A DEM for the study area, with $30 \times 30 \mathrm{~m}^{2}$ spatial grids was downloaded from the Geospatial Data Cloud (http:// www.gscloud.cn/). From the DEM we extract a watershed as a model domain with an area of $116.3 \mathrm{~km}^{2}$ on the southeastern slope of the western Nyaiqentanglha Shan. The catchment consists of four valleys, which are termed Langkaku, Zuolai, Qiongmuda and Ranbuqu from west to east (Fig. 3a). Within the catchment, we catalog 16 modern glaciers occupying an area of $18.2 \mathrm{~km}^{2}$, nine of which are larger than $0.5 \mathrm{~km}^{2}$ with the largest glacier being $5.87 \mathrm{~km}^{2}$ in the Langkaku valley (Table 1). In the catchment, elevations rise from 4500 to $6300 \mathrm{~m}$ asl and down-valley floor slopes are $<10^{\circ}$. This makes the shallow ice approximation equations an appropriate model choice (Le Meur and Vincent, 2003; Leysinger Vieli and Gudmundsson, 2004). No ice thickness data exist within the catchment. To obtain the subglacial bed topography, we estimate ice thickness on the trimmed DEM using a simple procedure that assumes that glacier ice behaves as a perfectly plastic material such that ice thickness $(H)$ can be determined by surface slope $(\alpha)$ and basal shear stress $(\tau=100 \mathrm{kPa})$ from $H=\tau /(\rho g \sin \alpha)$. The subglacial bed topography is described by subtracting the estimated ice thickness from the $30 \times 30 \mathrm{~m}^{2}$ DEM grids.

We compile 30 years (1981-2010) of daily climate records of temperature and precipitation measured at the Dangxiong Station $\left(30^{\circ} 29^{\prime} \mathrm{N}, 91^{\circ} 06^{\prime} \mathrm{E}, 4200 \mathrm{~m}\right.$ asl), the nearest long-term meteorological station to our model domain. The daily temperature and precipitation records are then converted into monthly means and used as 'reference' variables for the interpolation on the $30 \times 30 \mathrm{~m}^{2}$ DEM grids. The station is located in the same basin as our model domain (southeast of the mountains), so the station can be representative of climate at the same elevation in the basin. Xie and others (2010) calculated the monthly temperature lapse rates based on 1 year (August 2006-July 2007) of temperature record from nine automatic weather stations (AWSs) set up on the southeastern slope of the western Nyainqentanglha Shan. The nine AWSs are located in the range of $30^{\circ} 28^{\prime}-30^{\circ} 32^{\prime} \mathrm{N}, 91^{\circ} 02^{\prime}-90^{\circ} 03^{\prime} \mathrm{E}$ and distributed at elevations between 4300 and $5500 \mathrm{~m}$ asl. Using the monthly averaged temperatures at the Dangxiong Station and the linear monthly temperature lapse rates (Table 2), we calculate the monthly temperature grids in the model domain. When modeling the glacier mass balance on the western Nyainqentanglha Shan, both Caidong and Sorteberg (2010) and Zhao and others (2014) adopted a precipitation-elevation gradient of $5 \% / 100 \mathrm{~m}$ from the observations of $\mathrm{Li}$ and others (1986) in the region. Here we use the precipitation-elevation gradient of $5 \% / 100 \mathrm{~m}$ and the monthly precipitations at Dangxiong station to calculate the monthly precipitation grids for the model domain. The glacier accumulation (monthly proportion of precipitation that falls as snow) is determined by the fraction of the month falling below the snowfall threshold $\left(T_{\mathrm{s}}\right)$ of $1^{\circ} \mathrm{C}$ (Anderson and others, 2006). Glacier ablation is calculated by the degree-day approach that considers the fraction of the month with temperature above $0^{\circ} \mathrm{C}$. The climatic input (temperature, precipitation) used to define the modern glacier distribution can then be systematically changed $(\Delta T$ : temperature change relative to present; $F_{\mathrm{p}}$ : precipitation as fractional value relative to modern) to simulate the glacier extents under hypothesized paleoclimatic conditions for the specific glacial stages.

\subsection{Model parameterization}

The mass-balance model calculates the net annual mass balance of each DEM cell and determines the accumulation 
Table 2. Monthly temperature lapse rates used in the model

\begin{tabular}{lcccccc}
\hline Month & Oct. & Nov. & Dec. & Jan. & Feb. & Mar. \\
\hline $\mathrm{d} T / \mathrm{d} z\left({ }^{\circ} \mathrm{C} \mathrm{km}^{-1}\right)$ & -6.3 & -6.0 & -3.9 & -4.6 & -5.8 & -6.0 \\
Month & Apr. & May & Jun. & Jul. & Aug. & Sep. \\
$\mathrm{d} T / \mathrm{d} z\left({ }^{\circ} \mathrm{C} \mathrm{km}^{-1}\right)$ & -6.5 & -7.0 & -7.2 & -7.2 & -6.7 & -6.5 \\
& & & & & & \\
\hline
\end{tabular}

and ablation areas for the modeled region. The transfer of mass between the accumulation and ablation areas is calculated based on the ice-flow model used in previous studies (e.g. Plummer and Phillips, 2003; Kessler and others, 2006). The coupled mass-balance and ice-flow model has parameters including snow and ice degree-day factors $\left(D D F_{\mathrm{s}}, D D F_{\mathrm{i}}\right)$, snowfall threshold $\left(T_{\mathrm{s}}\right)$, ice deformation and sliding coefficients $(A, B)$, and ice deformation versus sliding factor $(f)$. Based on the observational mass-balance data in the melt seasons of the year 2007-2008 on the Zhadang Glacier, western Nyainqentanglha Shan, Wu and others (2010) estimated the $D D F_{\mathrm{s}}$ to be $5.3 \mathrm{~mm}^{\circ} \mathrm{C}^{-1} \mathrm{~d}^{-1}$, and the $D D F_{\mathrm{i}}$ ranges from 4.0 to $14 \mathrm{~mm}^{\circ} \mathrm{C}^{-1} \mathrm{~d}^{-1}$. Because the $D D F_{\mathrm{i}}$ is highly uncertain relative to other parameters and has a direct impact on the mass-balance calculation, we choose to calibrate this parameter following the method developed by Xu (2014). Forced by the climate of the past 30 years (1981-2010), the model runs under different $D D F_{\mathrm{i}}$ (4.0-14 mm ${ }^{\circ} \mathrm{C}^{-1} \mathrm{~d}^{-1}$ ) to match the observed present glacier distribution. When the model best reproduces the observed glacier distribution in the model domain, we adopt the corresponding $D D F_{\mathrm{i}}$ value in the following modeling experiments. Moreover, we assume that the glaciers deposited these two sets of moraines when they were in or near equilibrium with the climate during the LGM and MIS 3 glacial stages, and thus a steady-state simulation can be made. For such steady-state glacier simulation, the net mass-balance gradient effectively constrains the glacier extent, and variations in the two ice transport processes of ice deformation and sliding lead to only a small modification in ice extent (Kessler and others, 2006). Therefore, we do not attempt to adjust the coefficients of ice deformation $(A)$ and sliding $(B)$ and prescribe values of $1.0 \times 10^{-7} \mathrm{a}^{-1} \mathrm{kPa}^{-3}$, $1.5 \times 10^{-3} \mathrm{~m} \mathrm{a}^{-1} \mathrm{kPa}^{-2}$ and 0.5 for the parameters $A, B$ and $f$, respectively, which are widely used in previous studies (Plummer and Phillips, 2003; Laabs and others, 2006; Refsnider and others, 2008).

\subsection{Model experiments}

Four sets of sensitivity tests are conducted by changing the climate variables from modern conditions and by evaluating location, extent and growth pattern of the resultant glaciers. The first experiment is to establish the degree of influence exerted by temperature change on glacier extent. In the experiment, incremental changes in temperature relative to present day $(\Delta T)$ from -0.5 to $-5.5^{\circ} \mathrm{C}$ (with a step of $0.5^{\circ}$ C) were applied uniformly across the model domain. As the simulated glacier extents approached the respective positions of the two moraine sets, the $\Delta T$ was changed by a $0.1^{\circ} \mathrm{C}$ step in subsequent simulations to obtain the bestfitting glacier extents with the geological field evidence. The second experiment is designed to test the glacier sensitivity to precipitation change. Using incremental changes in precipitation from 1.0 to 10.0 times present-day amount and no change in temperature, we will see how the glacier evolves in the model domain. Guided by the first two sensitivity tests, the third experiment sets a suite of $\Delta T-F_{\mathrm{p}}$ combinations to force the model. By fitting the simulated glaciers under these $\Delta T-F_{\mathrm{p}}$ combinations to the glacier extents constrained by the inner and outer moraine sets, we will identify the climate scenarios that support the LGM and mid-MIS 3 glacier extents. The model parameters that dominantly influence our paleoclimate estimates are $D D F_{\mathrm{i}}$ and $T_{\mathrm{s}}$ in the coupled mass-balance and ice-flow model. To evaluate the impacts of the two parameters on the paleoclimate inferences, the fourth experiment uses different parameter values of $D D F_{\mathrm{i}}\left(10.8\right.$ and $\left.12.8 \mathrm{~mm}{ }^{\circ} \mathrm{C}^{-1} \mathrm{~d}^{-1}\right)$ and $T_{\mathrm{s}}(0$ and $2{ }^{\circ} \mathrm{C}$ ) to estimate the LGM $\Delta T-F_{\mathrm{p}}$ combinations by reproducing the LGM glacier extent in the model domain.

\section{RESULTS}

By running multiple simulations under current climate conditions with different $D D F_{\mathrm{i}}$ values, we found that when the $D D F_{\mathrm{i}}$ is $11.8 \mathrm{~mm}{ }^{\circ} \mathrm{C}^{-1} \mathrm{~d}^{-1}$, the model can best reproduce the observed glacier distribution in the model domain (Fig. 3b). The modeled modern glaciers have a total area of $19.7 \mathrm{~km}^{2}$, comparable to the total area $\left(18.2 \mathrm{~km}^{2}\right)$ of the cataloged 16 modern glaciers. The total glacier volume was estimated to be $0.83 \mathrm{~km}^{3}$, with the maximum ice thickness of $167 \mathrm{~m}$ in the Langkaku valley where the largest modern glacier is located. For the four sensitivity experiments, we present key results as following.

\subsection{Step cooling with present precipitation}

Figure 4 shows steady-state ice conditions under the step cooling scenario in the first experiment. With temperature reductions between 0 and $-2.0^{\circ} \mathrm{C}$, the glaciers are constrained in the four individual valleys; between -2.0 and $-3.0^{\circ} \mathrm{C}$ lowering, the glaciers are characterized by widetongued shape; and beyond $-3.0^{\circ} \mathrm{C}$ the glaciers coalesce on the foreland of the mountain range. Figure 5 shows the changes in ice area and volume under incremental cooling from -0.5 to $-5.0^{\circ} \mathrm{C}$. For one specific cooling, the model demonstrates that the valley glaciers change somewhat more intensively than the wide-tongued and coalescing glaciers. When the temperature decrease is between -0.5 and $-2.5^{\circ} \mathrm{C}$, the glacier volume will rise from 2.45 to $6.41 \mathrm{~km}^{3}$ with the maximum ice thickness and area respectively increasing from 269 to $443 \mathrm{~m}$ and 32.2 to $55.5 \mathrm{~km}^{2}$. With imposed temperature reductions between -3.0 and $-5.0^{\circ} \mathrm{C}$, the glacier volume rises from 7.28 to $9.14 \mathrm{~km}^{3}$ with the maximum ice thickness and area increasing only from 452 to $468 \mathrm{~m}$ and 60.8 to $78.5 \mathrm{~km}^{2}$, respectively. These results demonstrate the sensitivity of the model to temperature changes without precipitation change relative to the present day. We find that the model can reproduce the glacier extents constrained by the inner and outer moraine sets under temperature decreases of -2.3 and $-3.2{ }^{\circ} \mathrm{C}$, respectively.

\subsection{Step precipitation increasing with present temperature condition}

When an incremental, spatially uniform precipitation increase is imposed across the region with no change in temperature, the general pattern of glacier growth is essentially 


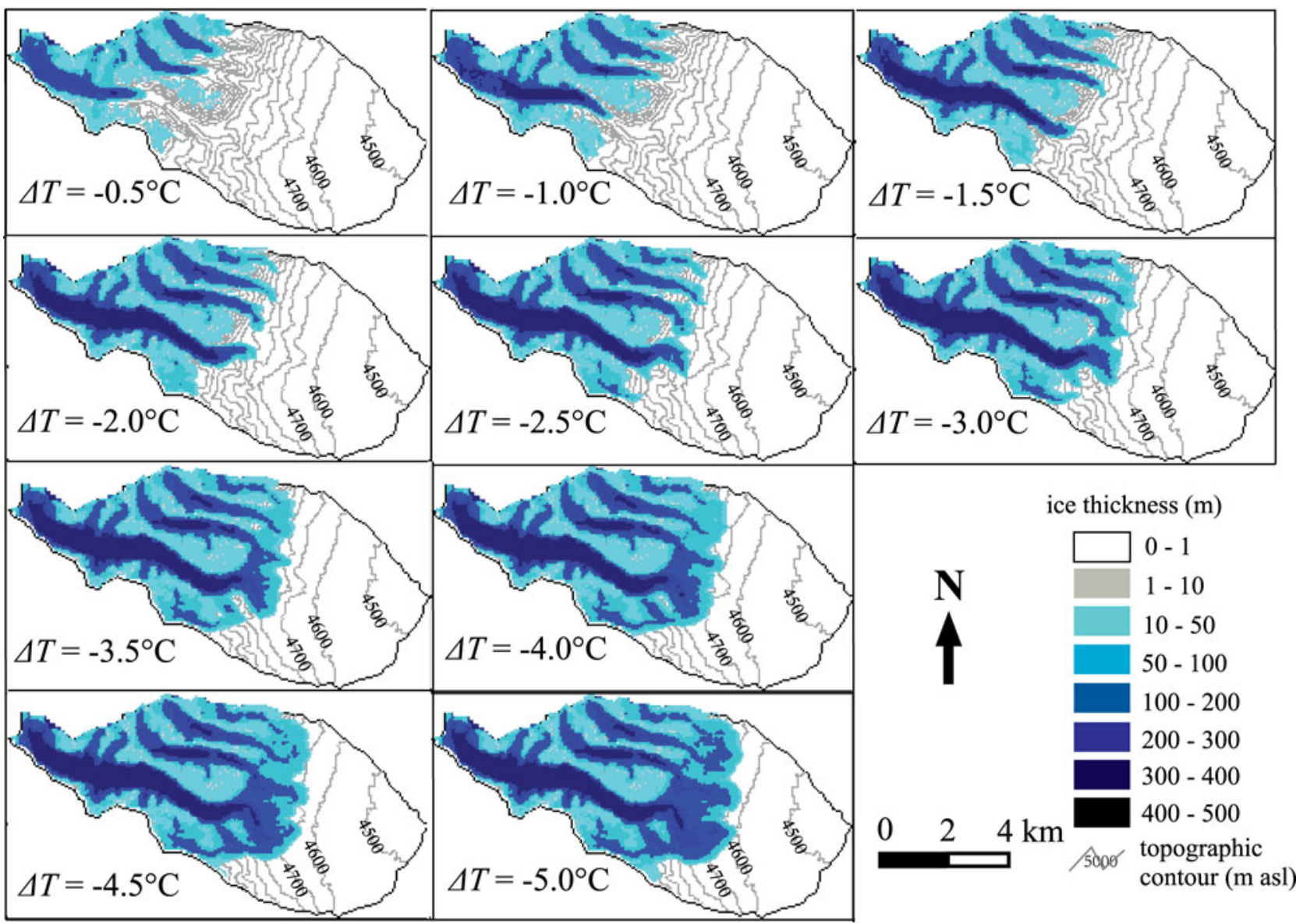

Fig. 4. Glacier growth under imposed step coolings of $0.5-5.0^{\circ} \mathrm{C}$ and present-day precipitation. Note that the glaciers vary from valley glaciers, through wide-tongued glaciers, to a coalescing glacier.

the same as that in the situation of progressive temperature cooling (not shown). With precipitation increases up to 3.0 times present-day precipitation, the glaciers are distributed in the four individual valleys; and beyond 4.5 times, the glaciers expand and coalesce on the foreland of the mountain range. When the precipitation is from 2.0 to 4.0 times present, the glacier volume rises from 3.66 to $7.80 \mathrm{~km}^{3}$ with the maximum ice thickness and area respectively increasing from 343 to $495 \mathrm{~m}$ and 38.9 to $53.4 \mathrm{~km}^{2}$. With precipitation from 5.0 to 7.0 times present, the glacier volume rises from 9.80 to $11.6 \mathrm{~km}^{3}$ with the maximum ice thickness and area increasing only from 527 to $569 \mathrm{~m}$ and 59.7 to $66.6 \mathrm{~km}^{2}$, respectively (Fig. 5). The model can reproduce the glacier extents constrained by the inner and outer moraine sets under the precipitation scenarios 3.5 and 5.5 times present, respectively. We also note that for one specific modeled glacier area, the modeled volume by precipitation increasing alone is larger than that by temperature cooling alone.

\subsection{Climate scenarios for the LGM and mid-MIS 3 glacier extents}

Guided by the first two sensitivity tests, incremental changes in $\Delta T$ from -0.5 to $-5.0^{\circ} \mathrm{C}$ and in $F_{\mathrm{p}}$ from 0.2 to 2.1 are applied uniformly across the model domain. By fitting the simulated glaciers under these $\Delta T-F_{\mathrm{p}}$ combinations to the glacier extents constrained by the inner and outer moraine sets, we identified the climate scenarios that support the LGM and mid-MIS 3 glacier extents (Fig. 6a). In this experiment, for one specific glacier extent the modeled glaciers have larger volumes in the wetter conditions and smaller volumes in the colder conditions. This is typically the case for the model when ice-flux parameters are kept constant (Plummer and Phillips, 2003).

All $\Delta T-F_{\mathrm{p}}$ combinations that can reproduce the LGM glacier extent are displayed on the upper curve in Figure 6a. Under these combinations, the modeled glaciers have an area of $\sim 50.9 \mathrm{~km}^{2}$; the modeled glacier volumes however vary from 5.58 to $5.72 \mathrm{~km}^{3}$ with the maximum ice thicknesses ranging from 411 to $442 \mathrm{~m}$. For the mid-MIS 3 glacier extent, all the successful $\Delta T-F_{\mathrm{p}}$ combinations are shown on the lower curve in Figure 6a. Under these combinations, the modeled glacier areas are $\sim 63.2 \mathrm{~km}^{2}$; the modeled glacier volumes however vary from 7.41 to 7.64 $\mathrm{km}^{3}$ with the maximum ice thickness ranging from 457 to $491 \mathrm{~m}$. Figure 7 shows the modeled net annual mass balances and corresponding ice extents for the LGM and midMIS 3 glacial stages that match well with the field geological data under the two $\Delta T-F_{\mathrm{p}}$ combinations of $\left(-3.6^{\circ} \mathrm{C}, 0.5\right)$ and $\left(-2.4^{\circ} \mathrm{C}, 1.5\right)$, respectively.

\subsection{Impact of $D D F_{\mathrm{i}}$ and $T_{\mathrm{s}}$ on the climate inferences}

To evaluate the impacts of the two parameters on the paleoclimate inferences, we performed the modeling experiments with different parameter values of $D D F_{\mathrm{i}}\left(10.8\right.$ and $12.8 \mathrm{~mm}^{\circ}$ $\left.\mathrm{C}^{-1} \mathrm{~d}^{-1}\right)$ and $T_{\mathrm{s}}\left(0\right.$ and $\left.2{ }^{\circ} \mathrm{C}\right)$ in attempts to reproduce the LGM glacier extent in the model domain. Figure $6 \mathrm{~b}$ shows the results of the model sensitivity test by varying the two 

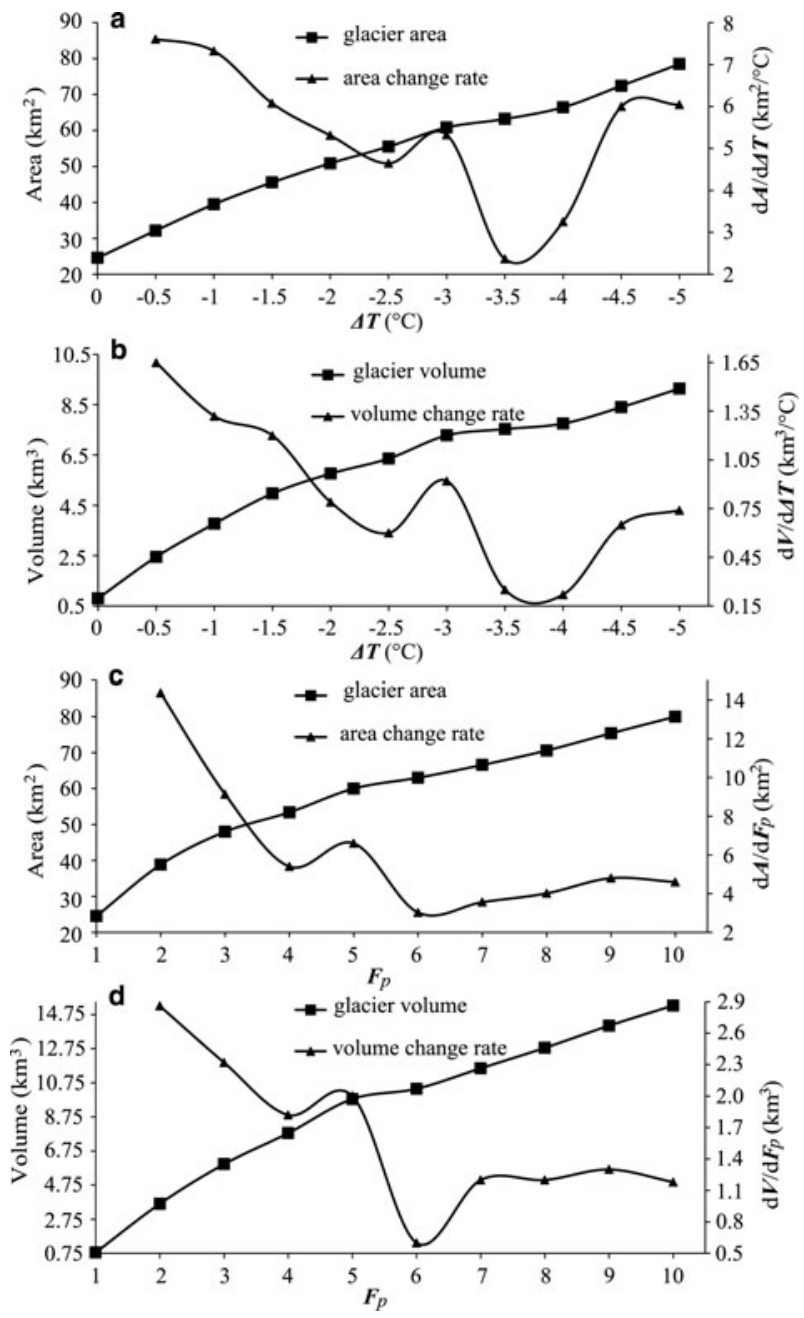

Fig. 5. Modeled glacier area, volume and their respective change rates as a function of the imposed step coolings of -0.5 to $-5.0^{\circ} \mathrm{C}$ $(\mathrm{a}, \mathrm{b})$ and step precipitation increases of 1-10 times present values (c, d).

parameters. The difference in modeled temperature lowering between using a $D D F_{\mathrm{i}}$ value of 10.8 and $12.8 \mathrm{~mm}^{\circ} \mathrm{C}^{-1} \mathrm{~d}^{-1}$ is -2.0 to $-2.9^{\circ} \mathrm{C}$, and the difference between a $T_{\mathrm{s}}$ value of 0 and $2^{\circ} \mathrm{C}$ is $1.1-1.4^{\circ} \mathrm{C}$. If $F_{\mathrm{p}}$ is set to 1 (under modern precipitation), varying the $D D F_{\mathrm{i}}$ by $\pm 1.0 \mathrm{~mm}^{\circ} \mathrm{C}^{-1} \mathrm{~d}^{-1}$ alone results in $\mathrm{a} \pm 1.3^{\circ} \mathrm{C}$ difference in $\Delta T$, and $\mathrm{a} \pm 1^{\circ} \mathrm{C}$ difference in $T_{\mathrm{s}}$ modifies $\Delta T$ by $\pm 0.7^{\circ} \mathrm{C}$. Likewise, if we set the $\Delta T$ to be $-3^{\circ} \mathrm{C}\left(3^{\circ} \mathrm{C}\right.$ temperature depression relative to modern), varying the $D D F_{\mathrm{i}}$ by $\pm 1.0 \mathrm{~mm}^{\circ} \mathrm{C}^{-1} \mathrm{~d}^{-1}$ alone results in a \pm 0.5 difference in $F_{\mathrm{p}}$ and $\mathrm{a} \pm 1^{\circ} \mathrm{C}$ difference in $T_{\mathrm{s}}$ modifies $F_{\mathrm{p}}$ by \pm 0.25 . Therefore, a difference of $\pm 0.5 \mathrm{~mm}^{\circ} \mathrm{C}^{-1} \mathrm{~d}^{-1}$ in $D D F_{\mathrm{i}}$ and variation of $\pm 1^{\circ} \mathrm{C}$ in $T_{\mathrm{s}}$ have approximately equal impact on our temperature and precipitation estimates. Similar results can be expected for the mid-MIS 3 glacial climate inferences, although we did not test for this glacial period.

\section{DISCUSSION}

Because glacier extent depends strongly on both temperature and precipitation, the results in this study do not provide a single paleoclimate solution for each of the two modeled glacial stages. However, the results do have implications for understanding patterns of glacier growth in response to climate change in the region, and the approximate magnitudes of climate change necessary to produce the LGM and mid-MIS 3 glacier extents. The differences in the inferred magnitude of climate change between LGM and mid-MIS 3 have further implications for understanding the likely driving mechanism for the glacier advances during the Last Glacial period.

\subsection{Glacier sensitivity to climate change}

In the step cooling and precipitation increasing experiments, the model reproduced the valley glaciers, wide-tongued glaciers and a larger coalescing glacier. The results of these experiments suggest that the valley glaciers respond more sensitively to a specific climate change than the larger wide-tongued and coalescing glaciers. For example, under $1^{\circ} \mathrm{C}$ cooling alone, the total volume of the modeled valley glaciers increases by $2.18 \mathrm{~km}^{3}$ on average, while the volume of the modeled coalescing glacier only increases by $1.17 \mathrm{~km}^{3}$. Moreover, the experiment results highlight that the dependence of glacier growth on temperature and/ or precipitation is nonlinear, although the glacier area and volume always increase under increasingly cold or wet climates (Fig. 5). By calculating change rates of the glacier area and volume curves, we are able to identify how the change rates of glacier area and volume evolve with respect to these equal and incremental cold or wet climates. Figures $5 \mathrm{a}$, b show that the change rates of glacier area $(\mathrm{d} A /$ $\mathrm{d} \Delta T)$ and volume $(\mathrm{d} V / \mathrm{d} \Delta T)$ decrease steadily with cooling between -0.5 and $-2.5^{\circ} \mathrm{C}$ as glaciers are constrained in the four individual valleys type, and once glaciers become wide-tongued glaciers with cooling between -2.5 and $-3.0^{\circ} \mathrm{C}$, the change rates slightly increase, probably reflecting the topographic difference between high-altitude valleys and low-altitude range forelands. Cooling between -3 and $-3.5^{\circ} \mathrm{C}$, however, leads to a decrease in the change rates as glaciers coalesce on the foreland, with temperatures colder than this leading to another increasing trend of change rates. Similar patterns can be seen when the increasing precipitation is imposed to force glacier growth (Figs 5c, d). The coupled mass-balance and ice-flow model directly uses climate (precipitation and temperature) data to determine net annual mass balance, and it runs on the DEM that describes topography of the model domain. Therefore, the varying characteristics of the modeled glacier area and volume change rates imply that some key climate-topography thresholds appear to exist in our model domain, which may control the formation process of different glaciers (Payne and Sugden, 1990). Although we did not simulate the recession of glaciers in the region, we predict the reverse to be true for recession scenarios (such as during deglaciation).

The model is a 2-D coupled approach where calculated grids of mass balance on a GIS are used as input to a glacier flow model. The algorithm solves for gridded mass balance first, and then calculates ice flow to an equilibrium state, indicating that in the model, mass balance is not dynamically coupled to flow regime. This prevents the exploration of how a specific paleoclimate scenario would have been reflected in glacier dynamics, erosion, or geomorphological formations. Also the model does not examine the timescale at which one specific glaciation responds to climate change. This therefore limits the interpretation for proposed climate shift, for example, from warmer/wetter conditions of more extensive mid-MIS 3 glacier extent to 


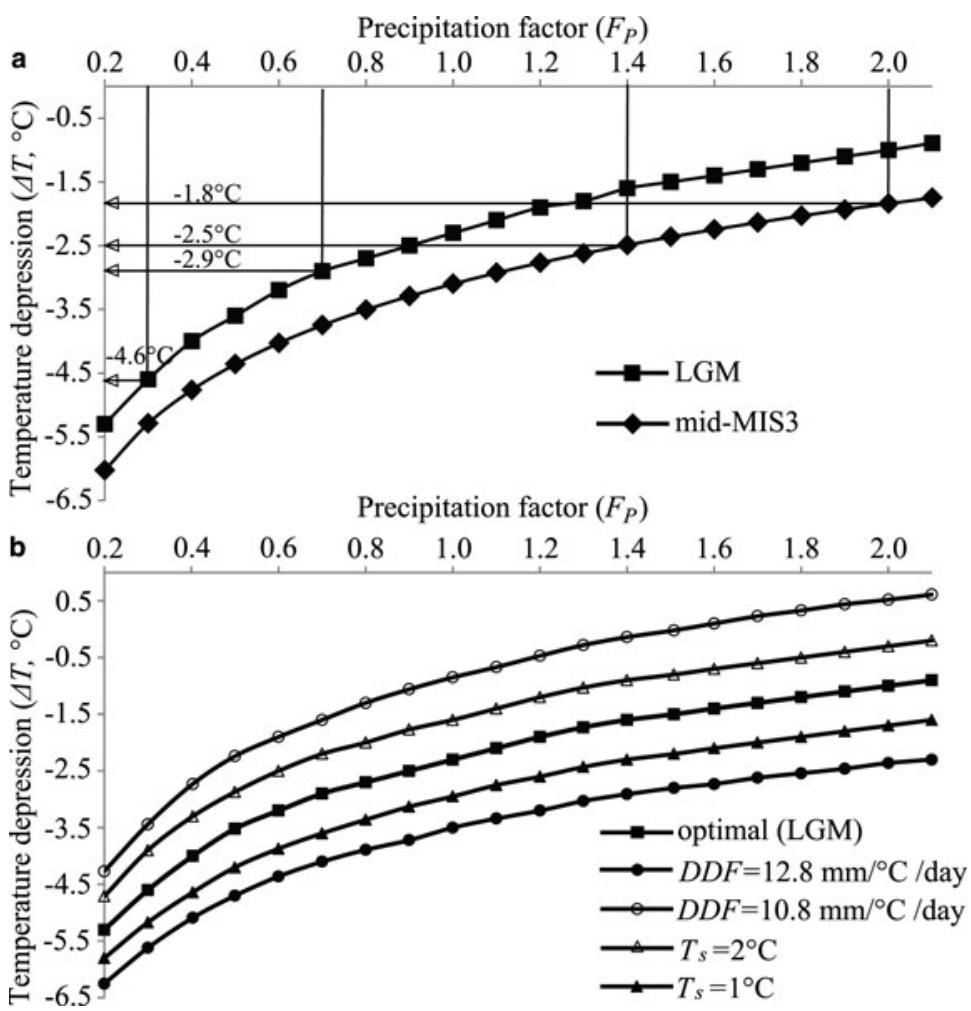

Fig. 6. Plots of the temperature and precipitation combinations $\left(\Delta T-F_{\mathrm{p}}\right)$ (a) that yield LGM and mid-MIS 3 glacial extents, respectively and (b) glacier-parameter sensitivity test for the LGM climate conditions.

colder/drier LGM conditions. However, the model indeed provides a means to hypothesize reasonable combinations of temperature and precipitation for the two sets of moraines in the region, although the ${ }^{10} \mathrm{Be}$ ages are not robust to constrain the mid-MIS 3 moraine set.

\subsection{Climate conditions during the Last Glacial}

For glacial stages of LGM and mid-MIS 3, our model simulations defined two specific sets of climatic $\Delta T-F_{\mathrm{p}}$ combinations that can reproduce respective glacial extents (Fig. 6a).
The curves denoted by the successful $\Delta T-F_{\mathrm{p}}$ combinations are essentially parallel between the two glacial stages. As Xu (2014) suggested, this characteristic is a result of the assumption that the seasonal patterns of temperature lapse rate and precipitation for each glacial stage modeling are the same as present. The estimates of $\Delta T-F_{\mathrm{p}}$ combinations shown in Figure $6 \mathrm{a}$ are the only possible climatic scenarios. To better constrain the ranges of the $\Delta T$ and $F_{\mathrm{p}}$, we have to recognize the general climate features for each of the two glacial stages.

The western Nyaiqentanglha Shan receives moisture, which is dominantly transported by the South Asian

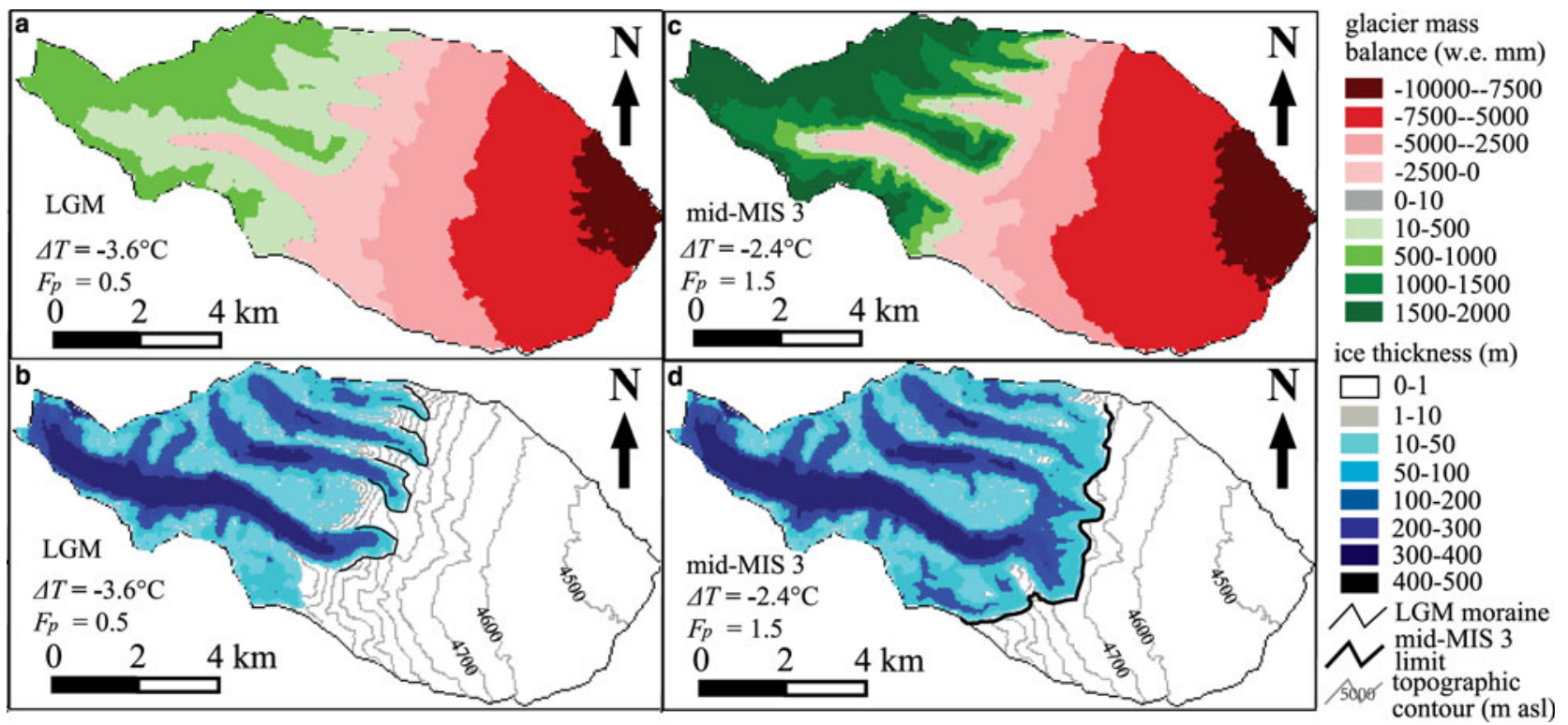

Fig. 7. Simulated glacier mass balances and extents for the LGM and mid-MIS 3 glacial stages under the $\Delta T-F_{\mathrm{p}}$ combinations of $\left(-3.6^{\circ} \mathrm{C}\right.$, $0.5)(a, b)$ and $\left(-2.4^{\circ} \mathrm{C}, 1.5\right)(\mathrm{c}, \mathrm{d})$, respectively. Note that the LGM and mid-MIS 3 glacier limits are also shown for comparison. 
summer monsoon from the Indian Ocean (Yatagai and Yasunari, 1998; Shi, 2002). As suggested by numerical simulations of atmospheric circulation patterns, the South Asian monsoon correlates well with the distribution of solar radiation as determined by the cyclical variability in the precession of the Earth's orbit (Clemens and others, 1991; Prell and Kutzbach, 1992). The precessional cycle of $30^{\circ} \mathrm{N}$ reveals strong summer insolation during MIS 3, which sometimes exceeds the present-day conditions and nearly equals early Holocene values, and subsequent to that the insolation steadily decreased and reached its minimum at the LGM (18-24 ka) (Berger and Loutre, 1991; Laskar and others, 2004). Furthermore, during the middle part of MIS 3 (MIS $3 \mathrm{~b}, 44-55 \mathrm{ka})$, the summer insolation is less than that during the early and late MIS 3, but is characterized by a northward increasing trend with latitude (Berger, 1978; Shi, 2002). This would be favorable for the establishment of low pressure over the Tibetan Plateau and high pressure over the southern subtropical Indian Ocean, and thus enhanced pressure gradient, strengthened monsoon and increased precipitation (Zonneveld and others, 1997; Shi and Yao, 2002). By considering the Northern Hemisphere summer radiation and glacial-interglacial ice-sheet boundary conditions, Prell and Kutzbach (1987) modeled the precipitation in South Asia and argued that it was drier than today during MIS 4 and LGM, and wetter in the interglacial period of MIS 3. Compiling 75 paleoclimatic records (mainly lake and loess records), Herzschuh (2006) reconstructed the moisture evolution history in monsoonal Central Asia during the last $50 \mathrm{ka}$. Most records from the area also yield a wet climate during the middle and late MIS 3, after which there were dry conditions (until the LGM). Furthermore, from multiple lines of evidence including pollen, periglacial phenomena and ice cores from the Tibetan Plateau, Shi and others $(1997,2001)$ proposed that during MIS 3 precipitation was $40-100 \%$ higher than today, while during the LGM precipitation was $30-70 \%$ lower than today. By referencing these precipitation-related reconstructions, this study tentatively constrains $F_{\mathrm{p}}$ values to be $0.3-0.7$ and 1.4-2.0 for the LGM and mid-MIS 3, respectively. Considering these precipitation amounts, our model results suggest that a temperature lowering between -2.9 and $-4.6^{\circ} \mathrm{C}$ is required to reproduce the LGM glacial extent, and a temperature lowering between -1.8 and $-2.5^{\circ} \mathrm{C}$ can support the mid-MIS 3 glacial extent in the model domain (Fig. 6a). This suggests that temperature depression is necessary to support the LGM and mid-MIS 3 glacier extents and that any reasonable scenario of precipitation change alone would not suffice. As shown in our experiments of step precipitation increases in the absence of temperature change, the LGM and mid-MIS 3 glacier extents require precipitation amounts of 3.5 and 5.5 times present, respectively. Such increases in precipitation are not consistent with the climate proxy data, indicating that temperature lowering is a necessary trigger for regional glaciation in the region. During the mid-MIS 3, the temperature lowering could be associated with less insolation relative to that during the early and late MIS 3 (Shi, 2002; Shi and Yao, 2002). Below we first consider our results in the context of other climate reconstructions in the southern Tibetan Plateau, and subsequently within the wider framework of the whole Tibetan Plateau.

The magnitudes of temperature changes necessary to produce the LGM and mid-MIS 3 glacier extents determined in this study are generally comparable with those found in other paleoclimate studies on the southern Tibetan Plateau. For example, in the Payuwang valley on northwestern slope of the western Nyaiqentanglha Shan, $\mathrm{Xu}$ and Glasser (2015) studied the glacier sensitivity to the equilibrium-line altitude (ELA) change. Based on the ELA depression, they inferred that during the LGM, the temperature was 3.3-4.4 ${ }^{\circ}$ C lower than the period of 2005-2008, and that the temperature during MIS 3 was slightly lower $\left(<1.5^{\circ} \mathrm{C}\right.$ lower $)$ than the period of 2005-2008. Using a similar modeling method to this study, Xu (2014) estimated the LGM temperature to be $4.0-5.9^{\circ} \mathrm{C}$ lower than present in the Yingpu Valley, Queer Shan and southeastern Tibetan Plateau. In addition, based on biogeographical data from ground beetles of the genus Trechus, and from juniper tree haplotypes, Schmidt and others (2011) suggested a maximum LGM temperature depression of $3-4^{\circ} \mathrm{C}$ in July for the southern Tibetan Plateau. Miehe and others (2011) also argued that Alpine steppes of Tibet persisted during the LGM with $3-4^{\circ} \mathrm{C}$ lower summer temperature, by hypothesizing that the Alpine steppes of the Tibetan highlands remained ecologically stable during the LGM.

In the wider context of the whole Tibetan Plateau, it appears that during the glacial periods of the LGM and mid-MIS 3, the magnitudes of temperature depression are larger on the northern Tibetan Plateau than on the southern part. For example, from the $\delta^{18} \mathrm{O}$ values of the Guliya ice core in the western Kunlun Shan, northwestern Tibetan Plateau, it was suggested that during the mid-MIS 3, the temperature was $\sim 5^{\circ} \mathrm{C}$ lower than today; and during the LGM, the mean annual temperature was $6-9^{\circ} \mathrm{C}$ lower than today (Shi and others, 1997, 2001). Using a climate-glacier modeling method in the Kuzigun Valley, northwestern Tibetan Plateau, Xu and others (2014) showed that the LGM climate was $4-9^{\circ} \mathrm{C}$ colder than today. Moreover, based on the ELA depression in the Dalijia Shan, northeastern Tibetan Plateau, Wang and others (2015) argued that during the mid-MIS 3 temperature depression was $3.3-6.8^{\circ} \mathrm{C}$. These estimates of temperature lowering are larger than in the southern Tibetan Plateau. This may reflect different degrees to which the Northern Hemisphere ice sheets influenced the northern and southern parts of the Tibetan Plateau during the glacial periods, as the climate of the northern Tibetan Plateau tended to be tuned to the climatic rhythm of the high northern latitudes by storm tracks of cold air and westerly circulations (Porter and An, 1995; Benn and Owen, 1998; Zhou and others, 1999; Seong and others, 2009).

\section{CONCLUSIONS}

In this paper, we tested glacier sensitivity to climate changes and inferred the climate conditions that could have supported the LGM and mid-MIS 3 glacier extents on the southeastern slope of the western Nyaiqentanglha Shan, using a coupled mass-balance and ice-flow model and guiding constraints from glacial geological data. Our sensitivity experiments explored glacier growth in response to temperature depression and precipitation increases. In the sensitivity experiments, the model reproduced the valley glaciers, wide-tongued glaciers and a coalescing glacier. The experiment results showed that the dependence of glacier growth on temperature and/or precipitation is nonlinear. It can also be concluded that on the southeastern slope of the western 
Nyaiqentanglha Shan, temperature depression is necessary to support the LGM and MIS 3 glacier extents and that any reasonable scenario of precipitation change alone would not suffice. Guided by field geological evidence and other independent paleoclimate reconstructions, the study constrained the more realistic temperatures to be $2.9-4.6^{\circ} \mathrm{C}$ and $1.8-2.5^{\circ} \mathrm{C}$ lower than present to support the glacier extents of the LGM and mid-MIS 3 glacial stages, respectively. Although the model did not dynamically couple the mass-balance to ice-flow regime and examined the timescale at which one specific glaciation responds to climate change, the temperature estimates for the two glacial periods are generally comparable with those found in other paleoclimate studies on the southern Tibetan Plateau. However, the last glacial temperature depressions estimated by the glacierclimate model are smaller than those reported from on the northern Tibetan Plateau.

\section{ACKNOWLEDGEMENTS}

This research was funded by the National Natural Science Foundation of China (NSFC, Grant No. 41471006, 41271018, 41230523), Strategic Priority Research Program (B) of the Chinese Academy of Sciences (XDB01020300), and State Key Laboratory of Cryospheric Sciences (SKLCSOP-2016-08). Sincere thanks to the three reviewers and especially the Scientific Editor (Rippin, David) for their constructive comments and suggestions on improving the work, and to Qian Zhang, and Yubin Wu for their help in the field work.

\section{REFERENCES}

Anderson B, Lawson WJ, Owens IF and Goodsell B (2006) Past and future mass balance of Ka Roimata o Hine Hukatere (Franz Josef Glacier). J. Glaciol., 52, 597-607 (doi: 10.3189/ 172756506781828449)

Benn DI and Owen LA (1998) The role of the Indian summer monsoon and the mid-latitude westerlies in Himalayan glaciation: review and speculative discussion. J. Geol. Soc., 155, 353-363 (doi: 10.1144/gsjgs.155.2.0353)

Berger AL (1978) Long-term variations of caloric insolation resulting from the Earth's orbital elements. Quat. Res., 9, 139-167

Berger AL and Loutre MF (1991) Insolation values for the climate of the last 10 million years. Quat. Sci. Rev., 10(4), 297-317 (doi: 10.1016/0277-3791(91)90033-Q)

Blard P-H, Lavé J, Pik R, Wagnon P and Bourlès D (2007) Persistence of full glacial conditions in the central Pacific until 15,000 years ago. Nature, 449, 591-594 (doi: 10.1038/nature06142)

Caidong C and Sorteberg A (2010) Modelled mass balance of Xibu glacier, Tibetan Plateau: sensitivity to climate change. J. Glaciol., 56(196), 235-248 (doi: 10.3189/002214310791968467)

Chevalier M-L and 8 others (2011) Constraints on the late Quaternary glaciations in Tibet from cosmogenic exposure ages of moraine surface. Quat. Sci. Rev., 30(5/6), 528-554 (doi: 10.1016/j.quascirev.2010.11.005)

Clemens S, Prell W, Murray D, Shimmield G and Weedon G (1991) Forcing mechanisms of the Indian Ocean monsoon. Nature, 353, 720-725 (doi: 10.1038/353720a0)

Dong G, Yi C and Caffee M (2014) ${ }^{10}$ Be dating of boulders on moraines from the last glacial period in the Nyainqentanglha mountains, Tibet. Sci. China (Earth Sci.), 57(2), 221-231

Dortch JM, Owen LA and Caffee MW (2013) Timing and climatic drivers for glaciation across semi-arid western HimalayanTibetan orogeny. Quat. Sci. Rev., 78, 188-208 (doi: 10.1016/j. quascirev.2013.07.025)

Finkel RC, Owen LA, Barnard PL and Caffee MW (2003) Beryllium10 dating of Mount Everest moraines indicates a strong monsoonal influence and glacial synchroneity throughout the Himalaya. Geology, 31, 561-564

Herzschuh U (2006) Palaeo-moisture evolution in monsoon Central Asia during the last 50,000 years. Quat. Sci. Rev., 25(1/2), 163178 (doi: 10.1016/j.quascirev.2005.02.006)

Heyman J (2014) Paleoglaciation of the Tibetan Plateau and surrounding mountains based on exposure ages and ELA depression estimates. Quat. Sci. Rev., 91, 30-41 (doi: 10.1016/j.quascirev. 2014.03.018)

Hostetler SW and Clark PU (2000) Tropical climate at the last glacial maximum inferred from glacier mass-balance modeling. Science, 290(5497), 1747-1750 (doi: 10.1126/science.290.5497.1747)

Kessler MA, Anderson RS and Stock GM (2006) Modeling topographic and climatic control of east-west asymmetry in Sierra Nevada glacier length during the Last Glacial Maximum. J. Geophys. Res., 111, F02002 (doi: 10.1029/2005JF000365)

Laabs BJC, Plummer MA and Mickelson DM (2006) Climate during the Last Glacial Maximum in the Wasatch and southern Uinta Mountains inferred from glacier modelling. Geomorphology, 75(2/3), 300-317 (doi: 10.1016/j.geomorph.2005.07.026)

Lal D (1991) Cosmic ray labeling of erosion surfaces: in situ nuclide production rates and erosion models. Earth Planet. Sci. Lett., 104, 429-439 (doi: 10.1016/0012-821X(91)90220-C)

Laskar J and 5 others (2004) A long-term numerical solution for the insolation quantities of the earth. Astron. Astrophys., 428, 261285 (doi: 10.1051/004-6361:20041335)

Le Meur E and Vincent C (2003) A two-dimensional shallow ice-flow model of Glacier de Saint-Sorlin, France. J. Glaciol., 49(167), 527-538 (doi: 10.3189/172756503781830421)

Leysinger Vieli GJC and Gudmundsson GH (2004) On estimating length fluctuations of glaciers caused by changes in climatic forcing. J. Geophys. Res., 109, F01007 (doi: 10.1029/2003JF000027)

Li J and 6 others (1986) Glaciers in Tibet. Science Press, Beijing

Miehe $G$ and 6 others (2011) Ecological stability during the LGM and the mid-Holocene in the Alpine Steppes of Tibet. Quat. Res., 76(2), 243-252 (doi: 10.1016/j.yqres.2011.06.002)

Molnar P and England P (1990) Late Cenozoic uplift of mountainranges and global climate change-chicken or egg. Nature, $\mathbf{3 4 6}$ 29-34 (doi: 10.1038/346029a0)

Murari MK and 8 others (2014) Timing and climatic drivers for glaciation across monsoon-influenced regions of the HimalayanTibetan orogeny. Quat. Sci. Rev., 88, 159-182 (doi: 10.1016/j. quascirev.2014.01.013)

Owen LA and Benn DI (2005) Equilibrium-line altitudes of the Last Glacial Maximum for the Himalaya and Tibet: an assessment and evaluation of results. Quat. Int., 138/139, 55-78 (doi: 10.1016/j.quaint.2005.02.006)

Owen LA and Dortch JM (2014) Nature and timing of Quaternary glaciation in the Himalayan-Tibetan orogeny. Quat. Sci. Rev., 88, 14-54 (doi: 10.1016/j.quascirev.2013.11.016)

Owen LA and 6 others (2003) Timing and style of late Quaternary glaciation in northeastern Tibet. Geol. Soc. Am. Bull., 115(11), 1356-1364 (doi: 10.1130/B25314.1)

Owen LA and 6 others (2005) Climatic and topographic controls on the style and timing of Late Quaternary glaciation throughout Tibet and the Himalaya defined by ${ }^{10} \mathrm{Be}$ cosmogenic radionuclide surface exposure dating. Quat. Sci. Rev., 24(12/13), 1391-1411 (doi: 10.1016/j.quascirev.2004.10.014)

Owen LA, Caffee MW, Finkel RC and Seong YB (2008) Quaternary glaciation of the Himalayan-Tibetan orogeny. J. Quat. Sci., 23(6/ 7), 513-531 (doi: 10.1002/jqs.1203)

Payne A and Sugden D (1990) Topography and ice sheet growth. Earth Surf. Process. Landf., 15(7), 625-639 (doi: 10.1002/ esp.3290150705)

Plummer MA and Phillips FM (2003) A 2-D numerical model of snow/ice energy balance and ice flow for paleoclimatic interpretation of glacial geomorphic features. Quat. Sci. Rev., 22(14), 1389-1406 (doi: 10.1016/S0277-3791(03)00081-7)

Porter SC and An Z (1995) Correlation between climate events in the North Atlantic and China during the last glaciation. Nature, $\mathbf{3 7 5}$, 305-308 (doi: 10.1038/375305a0) 
Prell WL and Kutzbach JE (1987) Monsoon variability over the past 150,000 years. J. Geophys. Res., 92(D7), 8411-8425 (doi: 10.1029/JD092iD07p08411)

Prell WL and Kutzbach JE (1992) Sensitivity of the Indian monsoon to forcing parameters and implications for its evolution. Nature, 360, 647-652 (doi: 10.1038/360647a0)

Raymo ME and Ruddiman WF (1992) Tectonic forcing of late Cenozoic climate. Nature, 359, 117-122 (doi: 10.1038/ 359117a0)

Refsnider KA and 5 others (2008) Last Glacial Maximum climate inferences from cosmogenic dating and glacier modeling of the western Uinta ice field, Uinta Mountains, Utah. Quat. Res., 69 (1), 130-144 (doi: 10.1016/j.yqres.2007.10.014)

Schmidt J, Opgenoorth L, Martens J and Miehe G (2011) Neoendemic ground beetles and private tree haplotypes: two independent proxies attest a moderate last glacial maximum summer temperature depression of $3-4^{\circ} \mathrm{C}$ for the southern Tibetan Plateau. Quat. Sci. Rev., 30(15/16), 1918-1925 (doi: 10.1016/j.quascirev.2011.04.014)

Seong YB, Owen LA, Yi C and Finkel RC (2009) Quaternary glaciation of Muztag Ata and Kongur Shan: evidence for glacier response to rapid climate changes throughout the Late Glacial and Holocene in westernmost Tibet. Geol. Soc. Am. Bull., 121 (3/4), 348-365 (doi: 10.1130/B26339.1)

Shi Y (2002) Characteristics of Late Quaternary monsoon glaciation on the Tibetan Plateau and in East Asia. Quat. Int., 97/98, 79-91 (doi: 10.1016/S1040-6182(02)00053-8)

Shi Y and Yao T (2002) MIS 3b (54-44ka BP) cold period and glacial advance in middle and low latitudes. J. Glaciol. Geocryol., 21, 19 (in Chinese with English abstract)

Shi Y, Zheng B and Yao T (1997) Glaciers and environments during the Last Glacial Maximum (LGM) on the Tibetan Plateau. J. Glaciol. Geocryol., 19, 97-113 (in Chinese with English Abstract)

Shi Y, Zheng B and Su Z (2000) Glaciation, glacial-interglacial cycles and environmental changes in the Quaternary. In Shi YF, ed. Glaciers and Their Environments in China: Present, Past and Future. Science Press, Beijing, 320-355 (in Chinese)

Shi Y, Yu G, Liu X, Li B and Yao T (2001) Reconstruction of the 30$40 \mathrm{ka}$ BP enhanced Indian Monsoon climate based on geological records from the Tibetan Plateau. Palaeogeogr. Palaeoclimatol. Palaeoecol., 160, 69-83 (doi: 10.1016/S0031-0182(01)00216-4)

Stone JO (2000) Air pressure and cosmogenic isotope production. J. Geophys. Res., 105, 23753-23759 (doi: 10.1029/ 2000JB900181)

Wang J and 5 others (2013) Cosmogenic nuclide constraints on late Quaternary glacial chronology on the Dalijia Shan, northeastern Tibetan Plateau. Quat. Res., 79, 439-451 (doi: 10.1016/j. yqres.2013.01.004)

Wang J, Cui H, Harbor JM, Zheng L and Yao P (2015) Mid-MIS 3 climate inferred from reconstructing the Dalijia Shan ice cap, north-eastern Tibetan Plateau. J. Quat. Sci., 30, 558-568 (doi: 10.1002/jqs.2802)

Wu Q, Kang S, Gao T and Zhang Y (2010) The characteristics of the positive degree-day factors of the Zhadang glacier on the Nyainqentanglha range of Tibetan Plateau, and its application. J. Glaciol. Geocryol., 32, 891-897 (in Chinese with English abstract)

Xie J, Liu J, Du M and Wang Z (2010) Altitudinal distribution of air temperature over a southern slope of Nyainqentanglha Mountains, Tibetan Plateau. Sci. Geogr. Sin., 30, 113-118 (in Chinese with English abstract)

Xu X (2014) Climates during Late Quaternary glacier advances: glacier-climate modeling in the Yingpu Valley, eastern Tibetan Plateau. Quat. Sci. Rev., 101, 18-27 (doi: 10.1016/j. quascirev.2014.07.007)

Xu X and Glasser NF (2015) Glacier sensitivity to equilibrium line altitude and reconstruction for the Last Glacial cycle: glacier modeling in the Payuwang Valley, western Nyaiqentanggulha Shan, Tibetan Plateau. Palaeogeogr. Palaeoclimatol. Palaeoecol., 440, 614-620 (doi: 10.1016/j.palaeo.2015.09. 025)

Xu X, Hu G and Qiao B (2013) Last glacial maximum climate based on cosmogenic $10 \mathrm{Be}$ exposure ages and glacier modeling for the head of Tashkurgan Valley, northwest Tibetan Plateau. Quat. Sci. Rev., 80, 91-101 (doi: 10.1016/j.quascirev.2013.09.004)

Xu X, Dong G and Pan B (2014) Modeling glacier advances and related climate conditions during the last glaciation cycle in the Kuzigun Valley, Tashkurgan catchment on the northwest Tibetan Plateau. J. Quat. Sci., 29, 279-288 (doi: 10.1002/ jqs.2701)

Yatagai A and Yasunari T (1998) Variation of summer water vapor transport related to precipitation over and around the arid region in the interior of the Eurasian continent. J. Meteorol. Soc. Jpn., 76(5), 799-815

Yu W and 10 others (2013) Different region climate regimes and topography affect the changes in area and mass balance of glaciers on the north and south slopes of the same glacierized massif (the West Nyainqentanglha Range, Tibetan Plateau). J. Hydrol., 495, 64-73 (doi: 10.1016/j.jhydrol.2013.04.034)

Zhao L and 6 others (2014) Numerical simulations of Gurenhekou Glacier on the Tibetan Plateau. J. Glaciol., 60, 71-82 (doi: 10.3189/2014JoG13J126)

Zhou W and 5 others (1999) Teleconnection of climatic events between East Asia and polar, high latitude areas during the last deglaciation. Palaeogeogr. Palaeoclimatol. Palaeoecol., 152, 163-172 (doi: 10.1016/S0031-0182(99)00041-3)

Zonneveld KAF, Ganssen G, Troelstra S, Versteegh GJM and Visscher $H$ (1997) Mechanisms forcing abrupt fluctuations of the Indian Ocean summer monsoon during the last deglaciation. Quat. Sci. Rev., 16, 187-201 (doi: 10.1016/S0277-3791(96) 00049-2) 